\title{
8
}

\section{Rebound: The Return of Norwegian Shipping}

How do you accept the disappearance of an industry that for more than a century has been the most important source of foreign exchange, neutralizing the balance of trade deficit and enabling crucial imports? You don't. You take up the fight, look for solutions and try to adapt. And you accept that help may come from the most surprising quarters.

The old man was something of a legend in both Norwegian and international shipping. Born in Bergen at the start of the century, he left his native country at an early age to work and study in London in the interwar period. During the Second World War, Erling Dekke Næss had worked for Nortraship. In the first post-war decades, from a base in the United States, he built up one of the leading international shipping empires, operating his own and chartered vessels. As leader of the American Committee for Flags of Necessity, he was one of the most vocal supporters of Flags of Convenience, the low-cost institutional arrangement that primarily American and Greek shipowners used. ${ }^{1}$

Although he was based abroad, Dekke Næss had been a frequent visitor to his home town, and he had donated large sums of money to an

\footnotetext{
${ }^{1}$ The autobiographies Næss (1977) (in English) and Næss (1981) (in Norwegian) are among the best insider accounts of modern shipping; confer also Chap. 4.
} 
Institute for Shipping Research and to a first-class museum in Bergen, telling the history of the city's medieval roots. ${ }^{2}$ Now he had come back to his native country to offer his solution to the extreme crisis that haunted Norwegian shipping. The forum was a meeting of shipowners in Oslothe date was 11 January 1984.

The fundamental premise for the plan that Erling Dekke Næss presented, was a feature that had been characteristic of Norwegian shipping for more than a century: the fact that the ships served the world market, not Norwegian exporters and importers. This implied that the majority of the Norwegian-owned tonnage never visited ports in the home country. Consequently, given that Norwegian shipping was an international industry, its scope should be international.

The basis for Norway's competitiveness had changed during the 20th century. A starting position based on low-cost shipping, with old ships and superior seamanship, was replaced by a combination of economies of scale, automated ship operation and innovative specialized tonnage. Technology gave the Norwegians a competitive edge, and neutralized what had now become a labour cost disadvantage. When the shipping crisis struck, and the market became characterized by massive overcapacity, there was little reason to invest in new tonnage. When it was no longer possible to invest in labour-saving technologies, the Norwegian companies' ability to create competitive advantages was reduced. The country still had a well-functioning maritime infrastructure, high competence onshore and offshore, an affinity for the sea and long maritime traditions. However, in a cut-throat competitive situation, this was insufficient to remain afloat.

\section{The Low Point}

In the period from 1970 to 1987 the number of shipping companies operating in the international market fell by more than two-thirds and the newly established businesses were too few and far between to alleviate

\footnotetext{
${ }^{2}$ The author of this book was for a number of years affiliated with the shipping research institute that had been established by Næss' donation.
} 
Table 8.1 The development of important OECD fleets, 1973-1987

\begin{tabular}{lcccr}
\hline & $\begin{array}{l}\text { Fleet 1973 } \\
\text { (million dwt) }\end{array}$ & $\begin{array}{l}\text { Fleet 1980 } \\
\text { (million dwt) }\end{array}$ & $\begin{array}{l}\text { Fleet 1987 } \\
\text { (million dwt) }\end{array}$ & $\begin{array}{l}\text { Decline } \\
1973-1987 \\
\text { (per cent) }\end{array}$ \\
\hline Denmark & 6.51 & 8.70 & 6.96 & 6.9 \\
The Netherlands & 7.26 & 9.00 & 5.12 & -29.5 \\
Sweden & 8.8 & 13.52 & 2.40 & -72.7 \\
Germany & 12.15 & 13.33 & 5.66 & -53.4 \\
Italy & 13.19 & 17.95 & 12.18 & -7.6 \\
France & 13.29 & 20.86 & 8.41 & -36.7 \\
Greece & 31.44 & 67.05 & 42.78 & 36.1 \\
Norway & 40.09 & 38.89 & 9.66 & -75.9 \\
The UK & 47.16 & 43.18 & 11.68 & -75.2 \\
Japan & 58.59 & 67.32 & 54.67 & -6.7 \\
Ten country & 238.48 & 299.80 & 159.52 & -33.11 \\
$\quad$ total & & & & \\
\hline
\end{tabular}

Sources: OECD, Maritime Transport, various issues. Confer footnote

the losses to any great extent. From 1970 to 1987 there were only three years when the number of companies increased. On average 15 companies disappeared every year, while only nine new companies were established. There was also a marked acceleration towards the end of the period; in both 1985 and 1986 more than 30 companies sold or transferred their last ships under the Norwegian flag.

Table 8.1 illustrates the massive decline in the fleets of the most important Organization for Economic Cooperation and Development (OECD) nations, and also shows that Norway was harder hit by the crisis than other European countries. ${ }^{3}$ Only Denmark and Greece saw their fleets increase from 1973 to 1987 , but even these "relative winners" experienced tonnage flight in the first part of the 1980s.

The UK continued the relative decline that had characterized the country for most of the 20th century and saw the largest tonnage loss in absolute terms. In fact, the amount of shipping tonnage that disappeared from the British flag in the period 1980-1987 was larger than the whole UK tonnage in 1900, when the UK controlled around half of the world fleet. This says something about how much the world fleet had increased in those eight decades, but also indicates the extent of the flight from the

\footnotetext{
${ }^{3}$ Based on various issues of OECD, Maritime Transport; confer Tenold (2000, 156-158).
} 
flag. In relative terms, the Norwegian experience was even more dramatic, but only barely so - in both the UK and in Norway the merchant marine fell by more than three-quarters. The decline also started earlier-in contrast to other countries, the UK and Norway had less tonnage in 1980 than in 1973.

In May 1987, less than 100 ships larger than 15,000 dwt remained, and half of these were already in the process of being transferred to Flags of Convenience-only bureaucratic slowness kept them on the Norwegian register. As a point of comparison, in 1973 there were more than 600 such vessels in the fleet, and Norwegian owners also had more than 200 such ships on order. ${ }^{4}$ From more than 800 to less than 100 is a massive reduction, and the press reported that the Norwegian merchant marine had gone "from being a giant to being a dwarf."

Norwegian shipping was on its death bed and awaiting the last rites. But, instead of the four horsemen of the apocalypse, the combination of a clever political manoeuvre and a rapidly improving market appeared on the horizon.

\section{The Kiss of Life: The Norwegian International Ship Register}

The idea of an international register, which Erling Dekke Næss in 1984 presented as the solution to the problems, was first received with little enthusiasm. Large-scale sales to foreign owners and the illusion of "temporary" flagging out to low-cost registries clearly showed that shipping companies could no longer be competitive when flying the Norwegian flag. However, this new reality was difficult to accept. Most shipping industry associations, the authorities and, in particular, the seafarers' unions, were negative about the idea of a "second" or "open" register where foreign labour could be used. Even the Norwegian Shipowners' Association was lukewarm. Its main concern was access to register ships

\footnotetext{
${ }^{4}$ Estimated on the basis of the Veritas-database, see Tenold (2001) for a presentation, and the list of Norwegian newbuilding contracts in Norwegian Shipping News, 2A, 1974, 41-63.

${ }^{5}$ NTB, 200587.
} 
abroad, and it probably feared that an inferior Norwegian solution might lead to the reintroduction of restrictions on the use of foreign flags.

Nobody took responsibility for the Norwegian predicament. The seafarers and the government blamed the shipowners, who had been greedy and had taken on too much risk. The shipowners blamed the government for its tax and labour policies, and the trade unions for their wage demands and expensive social requirements. At first, everybody blamed the markets. Then, everybody blamed foreign competitors. Still, with the massive outflow of tonnage in 1985 and 1986, it was evident that the old template was no longer sustainable. World shipping had gone through massive changes, both in technological and organizational terms. Norway had only participated in the first of these transformations.

In 1967, when the Norwegian Shipowners' Association's Managing Director, David Vikøren, presented Norwegian maritime policy at an international conference, he emphasized the fact that Norwegian shipping had "maximum freedom to combine the factors of production as efficiently as possible, regardless of national considerations." 6 The term "maximum freedom" is revealing. At the time, the "factors of production" appeared to be mainly the ship itself, and the important elements in this respect were access to ships, finance, insurance and markets abroad. The restrictions on the nationality of the seafarers were not taken into account. The ban on the use of Flags of Convenience was not even mentioned.

This perception of reality was gradually challenged-by the shipping crisis, by strong relative growth in Norwegian labour costs, and by the changes in the organization of world shipping, including the increasing use of Flags of Convenience. From 1980 to 1987 more than 15,000 jobs for Norwegian seafarers disappeared as a result of sales and flagging out; "the 1980s turned into a painful blood-letting that threatened to wipe out the Norwegian seafarers." The old ideas of what "Norwegian shipping" should and could be had to be reformulated. Gradually, the shipping organizations, the authorities and the seamen's associations were forced to acknowledge the need for change.

\footnotetext{
${ }^{6}$ Vikøren $(1967,8)$.

${ }^{7}$ Bakka (1999, 8).
} 
In 1981 a Parliamentary committee on shipping unanimously supported the idea that Norwegian shipping should be based on Norwegian ships, displaying the Norwegian flag and employing Norwegian seafarers. ${ }^{8}$ Gradually the crisis forced a relaxation of the requirements. The ban, with minor exceptions, turned into temporary permissions. The temporary permissions turned into permanent access, with minor exceptions.

Free access to register ships abroad had been one of the main strategies of the Norwegian Shipowners' Association. There was initially a reluctance to accept the ideas about the Norwegian International Ship Register (NIS). However, as the crisis became broader and more intense, a working party, established in late 1985 and led by Egil Abrahamsen from the classification society Det Norske Veritas, reformulated the goals and the policy. At this point, shipping policy became maritime policy. By considering the fate of the whole maritime community — not only the shipping companies, but auxiliary service industries, shipbuilders and so on-the effects became more visible and weightier. Political clout improved.

Norges Rederforbund [the Norwegian Shipowners' Association] had good political connections, in particular in Høyre [the Conservative Party]. The Prime Minister, Kåre Willoch, had worked for the association in the 1950s, and he still received a salary from Norges Rederforbund when he was a Member of Parliament. ${ }^{9}$ The association was known as one of Norway's most efficient lobbying organizations, and now it was fighting for its life. When the shipowners changed their minds, the politicians followed suit. In April 1986 the Conservative government referred to the current problems in shipping when it announced its aim to establish an international register. However, a change of government led to a postponement, as the new Labour government wanted to confer more closely with the unions.

That consultation took around a year, and led to a deterioration in the relationship between the Labour Party and the main trade union, and in particular among the various trade unions representing seafarers. The Act

\footnotetext{
${ }^{8}$ See Tenold (2001, 117-123) for a detailed presentation of the political process leading up to the establishment of the NIS.

${ }^{9}$ Verdens Gang, 150282, 12; formally, another lobby organization paid Willoch, but half of this salary was reimbursed from the shipowners; see Espeli $(1999,46)$. He did not receive such a salary during the period in question, when he was Prime Minister.
} 
establishing the NIS had a long and cumbersome journey through the Norwegian political system. The Socialist Left Party (and two dissenting Labour Party members) voted against the establishment, while the Progress Party wanted fewer restrictions, and suggested that NIS vessels should be exempt from Norway's economic boycott of Namibia and South Africa. ${ }^{10}$

The seamen's organizations were extremely negative to what they referred to as "wage-based apartheid" on Norwegian ships-for a long time they were against any system in which Norwegian and foreigners would receive different wages. ${ }^{11}$ They denounced the "racism, slavery conditions, starvation wages and lawlessness" that the NIS would introduce. ${ }^{12}$ This was a two-faced stance, however: internationalization had already reached the seamen's organizations. Norsk Sjømannsforbund had since 1983 operated a hiring office in Manila, where sailors-if they paid fees to the Norwegian union-could be employed on Norwegian vessels without triggering the boycott threat. This was a pragmatic approach with long traditions-in the 1950s Norwegian seafarers were urged not to sign on Panama-registered vessels, unless they were given a contract in which the seamen's organizations in the United States had accepted the salary and the working conditions.

At a conference in Oslo in 1948, the International Transport Workers' Federation decided to introduce a boycott of Flags of Convenience and throughout the post-war period the Norwegian seafarers' organizations had a more hard-line approach to such registers than similar unions in other countries. The Greek shipping organization in London went so far as to claim that the motivation for the Norwegian fight against Flags of Convenience was to stop the expansion of Greek-owned shipping. ${ }^{13}$ Gradually, the stigma associated with such flags disappeared. By the middle of the 1980s the Norwegians had not only embraced Flags of Convenience-they had come up with an alternative arrangement.

\footnotetext{
${ }^{10}$ Norway, Parliament (1986-87) Stortingsforhandlinger 3. juni 1987, 79.

${ }^{11}$ Peter Myklebust, Norsk Sjømannsforbund, NTB 240186. See also Bakka (1999).

${ }^{12}$ Aftenposten, 070487, 46.

${ }^{13}$ Jenssen (1999, 204-213).
} 
The political process was long and winding, but the bureaucratic response was surprisingly swift. During the consultation, the shipowners' association had suggested that the register should be opened in January 1988. The Shipping Directorate, however, promised that the moment the politicians had made the decision, it would act rapidly. Moreover, parallel with the preparations for the new register, the legal regime would go through significant simplification and rationalization.

The aim was to establish a competitive Norwegian alternative to Flags of Convenience. Consequently, the red tape had to be limited and much of the control function was delegated to the leading international classification societies. ${ }^{14}$ The new registries, NIS for international vessels and NOR (Norwegian Ordinary Register) for ships operating in Norwegian waters, were organized under the auspices of the town clerk [Byskriver] in Bergen. As a result of the impressive bureaucratic swiftness, they opened for business on 1 July 1987. Outside the offices, huge crowds were protesting. Inside the offices, the revitalization of Norwegian shipping had begun.

When NIS was formally opened in the summer of 1987, the Norwegian-registered fleet consisted of slightly less than 500 ships, totalling 8.9 million dead weight tons (dwt), with a similar number owned from Norway but registered abroad. Because there had been a tendency to flag out relatively large ships, the fleet under foreign flags amounted to almost 16 million dwt. ${ }^{15}$ After NIS was established there was an influx of ships from the conventional registry, but this reregistration was more or less over by the end of 1988 .

One condition for NIS-registry was that the owner had a collective agreement with a Norwegian or foreign union. In the early 1990s four such agreements existed; for Nordic seafarers, for Filipinos and Indians, for Polish seafarers and for Pakistani and Indonesian seafarers. ${ }^{16}$ As such, the Register can be seen as a vehicle of international solidarity, and this was one of the reasons that a Labour government was willing to introduce such an arrangement. The NIS enabled employment for seafarers from

\footnotetext{
${ }^{14}$ See Vigtel (1988, 87-90) and Bakka (2017, 180-181).

${ }^{15}$ Norway, Parliament (1988-89) Stortingsmelding nr. 39 (1988-89), 7.

${ }^{16}$ Jenssen $(1999,216)$.
} 
poor countries, but on acceptable terms. For a country that prided itself on its "foreign aid," this was another means of north-south transfer. However, the establishment of the NIS did not imply that foreigners for the first time were employed on Norwegian ships-it just meant that for new groups of foreigners, certain minimum conditions were met.

Before NIS, there were legal restrictions on the extent to which it was possible to use foreign labour. ${ }^{17}$ The most numerous and most wellknown group consisted of other European seafarers; in the 1950s particularly from Denmark and Sweden, and in the 1960s and 1970s increasingly from Southern Europe. In the early 1950s around a quarter of the foreigners on Norwegian ships came from Denmark. Ten years later around a third of the foreign seafarers came from Spain, while the proportion of Danes had fallen to less than 10 per cent. There were several reasons that Norway had to "import" foreign seafarers; the strong growth of the fleet, labour-demanding reconstruction, expansion within education and manufacturing employment onshore, as well as the relatively small cohorts from the 1930s coming of age.

The Europeans had functioned as "swing capacity" - ensuring that there were sufficient seamen during the tight labour market in the 1950s and 1960s, but disappearing when the market became difficult in the 1970s and 1980s. ${ }^{18}$ The foreign seafarers were particularly hard hit by vessel sales and rationalization. Given that they were given the same terms as Norwegians, there were no financial incentives behind the employment. The practice had two main reasons. First, it was part of the "international" market for seamen-which had its counterpart in Norwegian seafarers working for ships registered in other countries. Second, it reflected the difficulties of recruitment in a Norwegian economy where attractive employment alternatives were no longer scarce.

The second group of foreign seafarers on Norwegian ships was not employed on Norwegian terms, and there were both practical and cost reasons for its recruitment. Ships trading in East and Southeast Asia had been allowed to take on local crews, who were signed on en bloc from local

\footnotetext{
${ }^{17}$ See Halvorsen (2010) for a concise analysis of foreigners working on Norwegian ships in the period 1950-1975.

${ }^{18}$ See the analysis in Tenold (2015b).
} 
crewing agencies. This practice went back to the start of the century, and a waiver from the normal nationality and tariff requirements was given to ships where the officers were Norwegian. ${ }^{19}$ This scheme, where all or practically all of the crew were Asian, had included as many as 150 ships in the middle of the 1960s. Many of these vessels were typically older and labour intensive, and had lost out in the competition in the world market as a result of rapid technological development. However, there were also shipping companies that had specialized in the requirements of this trade. The "Asian-clause" vessels were gradually phased out. At the end of the 1960s, it was estimated that around 100 ships operated under such terms, but the number declined rapidly in the 1970s. By the middle of the 1970s the number had been halved, and by the early 1980 s only 15 such ships were left. Some were flagged out, with continued Norwegian ownership interests, while some of the trade was taken over by local companies - at times helped by increasingly nationalistic policies. ${ }^{20}$

The least-documented use of foreign labour on Norwegian ships was found in African waters, where there was a long-standing tradition of taking on a supplemental "crew" in the shape of "krooboys"-local labour that performed non-nautical tasks such as hull cleaning, washing, painting, rust picking, general maintenance and so on. "Krooboys" are first mentioned in Norwegian newspapers as early as in $1880 .{ }^{21}$ The name has nothing to do with the word "crew," although it is similar to its phonetic spelling - the term was originally used for people from the coast of Kroo or Kru around Cape Palmas in Liberia, Western Africa, who were "journeymen [...] found on board of every vessel [along the African coast].” However, in the Norwegian context "krooboys" became a generic term for all kinds of African casual labour. ${ }^{22}$

\footnotetext{
${ }^{19}$ Molaug (1977, 89-95).

${ }^{20}$ Norway, Parliament (1975-76) Stortingsmelding 23, 29 and Norway, Parliament (1986-87) Ot. prp. $45,7$.

${ }^{21}$ Hedemarkens Amtstidende, 08.12.1880, 2.

${ }^{22}$ Bacon $(1842,205)$. Kroomen were known as the strongest and best workers along the coast; see Phillips (1889, 463). For Norwegian ships, Madagascar became an important source of temporary casual labour on the other side of the continent. In the 19th century Royal Navy, it was not uncommon to employ Seedies recruited in the Indian Ocean (for instance the Seychelles or Zanzibar) and Kroomen recruited on the West Coast. For an overview of the problem of defining the group, see Tonkin (1974).
} 
By the 1970s the system was still in existence on some ships trading along the African coast-locals, usually led by an overseer or headman, lived on the deck and worked very long hours at extremely low wages. ${ }^{23}$ However, free food and the ability to profit from cast-offs from the ship and petty trading and barter along the coast, made the work sought after. The Africans had few alternative means of income, and the inhabitants of the "Kroo-town" in some African cities had a higher standard of living than the population in general. ${ }^{24}$ As Norwegian shipping changed, and the liner trade with frequent stops along the African coast was abandoned, the krooboys disappeared as well.

Before the shipping crisis, the idea that Norwegian ships should be mainly or completely manned by foreigners was alien even to the shipowners' organizations. However, by the middle of the 1980s, it was the only workable political reality. This change shows how much Norwegian shipping-and Norway-had developed in the 20th century. A book from the interwar period suggested that "as long as the sea flows outside the door of thousands of homes, as long as it lights the desire to explore and nourishes good seamanship, it is hardly likely that our most traditional industry will stagnate due to lack of suitable labour." 25 By the late 1980s the sea still flowed, but suitable_-in terms of suitably inexpensive-labour had to be obtained elsewhere.

\section{The Timing of Their Life}

The introduction of the Norwegian International Ship Register made it possible for Norwegian shipping companies to compete on equal terms with the most cost-efficient foreign competitors. The recipe was rapidly copied by other countries, but NIS was initially far more successful than similar measures elsewhere. ${ }^{26}$ A comparison of second registers from the

\footnotetext{
${ }^{23}$ Arbeiderbladet, 020872, 4 and Kvam (1971, 45-49).

${ }^{24}$ See the fascinating recollection of a trip with Krooboys on a Norwegian liner in the 1960 s in Bjørklund and Kolltveit (1989, 281-284).

${ }^{25}$ Egeland (1930, 4).

${ }^{26}$ In 1984 the Isle of Man became a second register for the UK, and the Dutch introduced the Netherlands Antilles, with an office in Curacao, in 1987. Both of these were "offshore" registers,
} 
early 1990s shows that while NIS consisted of some 40 million dwt, the closest challengers - Germany and Denmark — each amounted to around 7 million dwt. ${ }^{27}$

What can explain this rollercoaster development of the Norwegian fleet, from more than 48 million dwt in the beginning of 1977 to only around 10 million a decade later, before shooting back to almost 38 million dwt in 1991? ${ }^{28}$ The basis for the reduction is hopefully clear by nowthe combination of a collapsing market and unfortunate strategies. What about the rebound? The 57 million tons of shipping registered in Norway and elsewhere was an all-time high for the Norwegian-owned fleet, though the share of the world fleet - which was now slightly less than 9 per centhad been larger in the late 1960s. There are three main reasons for the rapid ascent after the 1987 nadir; one general, and two specific to Norway.

One reason for the strong growth was market developments. The tanker market slowly improved from 1985 onwards, as demand picked up and superfluous tonnage was scrapped. The cycle in the bulk market changed relatively abruptly in 1987 , with rates and values of some vessel classes more than doubling during the year. The fact that ship prices were extremely low-and that the vessels in many instances were owned by banks or other creditors without a long-term, operational scope-implied that it was relatively easy to enter the market. The market improvement was a tide that lifted all boats. Consequently, we have to look elsewhere to explain why Norway's international market share more than trebled from 1987 to $1990 .{ }^{29}$

The first specifically Norwegian reason was that many of the ships that had been flagged out - while ownership or control remained in Norway-

and were followed by Kerguelen, a "French Antarctic" registry in 1989. NIS was the first "domestic" open register, followed by Denmark and Germany in 1989 and Italy in 1998; see Carlisle (2009, 322) and Sornn-Friese and Iversen (2014).

${ }^{27}$ Sletmo and Holste (1993, 249-250).

${ }^{28}$ Data on the Norwegian fleet in December 1991 from UNCTAD, Maritime Transport 1991, 11. In addition to the almost 38 million carrying the Norwegian flag, UNCTAD estimates that there was a fleet of almost 19 million dwt flying foreign flags-in total, a fleet of 56,772,906 dwt. Fearnley \& Eger, Review 1991, 48, refers to a Norwegian fleet of 41 million dwt.

${ }^{29}$ The idea that all countries and companies are equally affected by a market improvement is a simplification: given the different development of the various shipping segments, not all boats are lifted equally. 
returned to the Norwegian flag. Although the register, as a public body, had a limited ability to market itself, the Bergen Shipowners' Association actively promoted the new possibilities. Foreign owners, if they had Norwegian representatives, could register ships in NIS, but the number of foreign-owned vessels entered into the register was very low. By the beginning of 1989 only around 30 foreign-owned ships were included, and by 1992 the foreign-owned share was less than 7 per cent of the total, so this played no important role in the growth. Vastly more important was the fact that Norwegian shipowners saw the register as attractive, both with regard to price and procedures. Moreover, the fact that it had been possible to arrive at a political solution-and one that ensured competitiveness while maintaining the link to Norway_created a sense of optimism.

This brings us to the final reason for the rebound: an impressive ability to mobilize capital and identify opportunities.

The crisis had taken its toll on the equity of Norwegian shipping companies, on the loan portfolios of the shipping banks and on the recruitment of personnel to ships and shipping company offices. The crisis had proved that shipping was a high-risk business. However, high risk also means high potential profits. The dream of these profits encouraged a massive wave of Norwegian investment. Norwegian investors were willing to take the risk-and they were eagerly encouraged by the authorities.

In fact, the latter element-the awakening of dormant Norwegian capital - was the most important factor behind the growth. Estimates from the beginning of the 1990s suggest that ships that had "returned home" made up around 20 per cent of the NIS fleet, while ships that had been bought second-hand abroad amounted to 60 per cent of the tonnage. In the period 1987-1991 more than 900 vessels were bought by Norwegian owners, and the majority would be registered in NIS. ${ }^{30}$

With the establishment of NIS, and the changing cost structure, completely new models of operation and ownership became possible. This led to increased diversification in the Norwegian fleet. Before it was possible to use low-cost foreign seafarers, only the most modern, advanced and specialized ships could afford to fly the Norwegian flag. Now it became

${ }^{30}$ Bakka (2017, 186-188). 
possible to compete on completely equal terms with foreigners, and there was no need to stick with "typically Norwegian" strategies. Consequently, relatively simple, older, second-hand tonnage was bought from abroad, leading to a high degree of diversification in the Norwegian fleet. By the early 1990s there were even suggestions that some of the ships that had been included in NIS were "substandard" and that the reputation of the register was at stake. ${ }^{31}$

\section{Old and New Hands on Deck}

The maritime historian Dag Bakka jr., who has written a very good account of the revitalization of the shipping industry after the introduction of the NIS, points out that three different types of "shipowners" put their mark on Norwegian shipping in the last part of the 20th century. ${ }^{32}$ The expansion was orchestrated by "the next generation,", which took over existing companies, a group of enterprising newcomers, as well as those that had survived the crisis; the old-timers.

The first group was a new generation of owners and managers, who took the helm in a number of traditional shipping companies-Bergesen, Kloster, Smedvig and Staubo. The extent to which their inheritance had any real value varied - in many cases the shipping crisis had depleted the value of the companies. However, they had a shipping pedigree, and access to national and international networks. Some of the companies had sailed relatively smoothly through the crisis, others started practically from scratch, with little more than a shipping "name" and a shipping reputation.

The second group consisted of experienced owners in established companies-Westfal-Larsen, Fred. Olsen, Leif Höegh and so on. Many of the older shipping companies had a more risk-adverse strategy than the fastest growers in the 1960s and 1970s - their growth was slower, but that also implied that their financial basis was sounder. As we have seen, they were on average more diversified, and had a larger portfolio of specialized

\footnotetext{
${ }^{31}$ Lloyd's List, 010492, 11.

${ }^{32}$ Bakka (2017, 186-187).
} 
ships, than the smaller companies. Some of the established companies collapsed during the crisis, while others were busy restructuring their balance sheets and biding their time until there were new profitable opportunities. In the most fertile instances, the established companies had been divided among different branches of the family, paving the way for expansion along parallel lines, both old and new.

In Bergen we find two very good examples of how competition between companies with a joint tradition could give strong growth. Kristian Gerhard Jebsen started his own business in the late 1960s, after leaving the family company, which was taken over by his younger brother, Atle Jebsen. The two brothers were among the most expansive shipowners in the 1980s and 1990s, investing heavily in the specialized bulk markets. Although they both had financial challenges, their companies were among the largest in Norway in the early 1990s. ${ }^{33}$ Similarly, when the second cousins, Dan Odfjell and Abraham Odfjell, divided the leading chemical tanker owner, Odfjell, in the 1970s, they both managed to build up companies that were in the Top Four of the chemical tanker market. This kind of growth-by spin-offs from established enterpriseswas not confined to Bergen. Various members of the Ugland family based in and around Grimstad on the South Coast, also made their mark, with investments in car carriers, shuttle tankers, bulk carriers and product tankers.

The final group consisted of a number of entrepreneurs, with various backgrounds, who used their skills and networks to create new business. Some came from shipping companies, others from shipbroking or finance. Among these we find John Fredriksen, who from a base in London would go on to become by far the biggest and most successful Norwegian shipowner in the first part of the new millennium. Another newcomer was Herbjørn Hansson, who had worked for Anders Jahre in the Kosmos-system. He built up a substantial tanker fleet by means of a company incorporated in Bermuda, but with operations in Norway. The strategy has been to raise funds from investors on the New York Stock Exchange, where a large number of shareholders saw shipping as an exotic industry and were seduced by the frequent payment of dividends.

\footnotetext{
${ }^{33}$ See Tenold (2015a) and Harvey (2005).
} 
Hansson's business model was quite unique in a Norwegian setting, but in an international perspective, a handful of Greek shipping companies followed the same strategy.

Sometimes the newcomers built their business on the ruins of older companies. Jens Ulltveit Moe had been appointed by the main creditor, Bergen Bank, to take over the management of the troubled Knutsen OAS in Haugesund, which had made unfortunate investments in large tankers. ${ }^{34}$ Together with Trygve Seglem, he built up a fleet of advanced Suezmax shuttle tankers. The phoenix-like Knutsen organization was primarily engaged in the operation and management of the ships-the investments funds very often originated from investors in limited partnerships [kommandittselskap] that had actual ownership of the vessels.

The kommandittselskap became the "typical" form of incorporation for many of the companies that expanded rapidly in the period around 1990 . The financial basis for this type of incorporation was the combination of limited liability with substantial tax deductions for the individual owners. For many investors, the tax advantages were the main motivation for the investments - in the worst cases, projects that had negative expected profits turned out to give a positive return when the tax effect was considered. A number of the projects also had an evident speculative character, where the main aim was "asset play" - a desire to reap the benefits of increasing vessel values - rather than revenue from long-term operation.

The limited partnerships were not only linked to deep-sea shippingthey became a favoured means of finance for offshore involvement as well. There had been a steady stream of shipping companies seeking out opportunities in connection with the expansion of the Norwegian offshore sector. First, during the period of high liquidity at the beginning of the 1970s. Second, as a means of diversification when the shipping market wobbled. Finally, as a viable business in its own right, for companies that had managed to build up knowledge about another maritime venture.

\footnotetext{
${ }^{34}$ See Hammerborg (2003, 386-395). Evidently not a big fan of mono-causal explanations, Hammerborg $(2003$, 386) explains Knutsen's success by the following factors: "luck, coincidence, personal competence, skill, the restructuring of the company, the creditors' patience, technological development, the oil activity in the North Sea and the access to venture capital through the kommandittselskap-scheme."
} 


\section{Returning Home in Search of Black Gold}

The 1970 s and 1980s were extremely dramatic, and the haemorrhaging of shipping companies during the crisis was unprecedented. The introduction of the Norwegian International Ship Register, which saved Norwegian shipping but sacrificed Norwegian seafarers, was a timely intervention by the authorities. Still, the new regime could not prevent the shipping industry from losing its previous hegemonic position in the economy in general, and in exports in particular. Net freight earningsthe profits that the shipping companies "brought back home" from abroad-had fallen from more than 23 per cent of total exports in the beginning of the 1970 s, to less than 4 per cent by $1987 .{ }^{35}$

The reduced importance of shipping in the Norwegian economy was not only caused by the difficult conditions in the shipping market and the reduction of the Norwegian fleet. The transformation of "Norwaythe shipping nation" to "Norway-the oil producer" also played a very important part. ${ }^{36}$ The export of crude petroleum and natural gas, which was non-existent in 1970, made up more than a third of Norwegian exports in the first half of the 1980s. During this turbulent period, growth in offshore petroleum exploration and exploitation became another outlet for maritime capital and maritime competence.

The relationship between Norwegian deep-sea shipping and offshore oil production is complex. The activity in the North Sea clearly diverted resources away from the shipping industry-both capital and labour found an attractive alternative. At the same time, with international shipping markets developing the way they did, some kind of constraint on the Norwegian exposure was clearly a good thing. Consequently, while the offshore sector temporarily reduced Norway's involvement in

\footnotetext{
${ }^{35}$ Calculated on the basis of Statistics Norway (1994, 532-533 and 544-545). Although the figures never returned to those of the Golden Age- even when we leave out petroleum exports—1987 was a low point.

${ }^{36}$ Gross freight earnings made up 37 per cent and net freight earnings 23.3 per cent of total exports in 1970 . By 1987 the shares had fallen to 13.8 per cent for gross freight earnings and 3.4 per cent for net freight earnings. This was partly a result of Norway's emergence as a major oil exporter but even if we exclude the effects of the petroleum exports, there is a substantial decline, to 18.9 and 4.6 per cent, respectively. Due to a smaller fleet and a lower freight rate level, the revenue from shipping declined in absolute terms as well.
} 
international shipping, the long-term effects were positive, for at least three reasons.

First, a number of shipping companies found another investment object that clearly provided a higher return on capital than the crisisridden shipping market. For some it provided revenue in difficult times, for others a completely new business model. Second, activity in the North Sea provided the maritime sector with a new base from which it became possible to build up competence and expand on the international stage. Third, for Norwegian seafarers - who were replaced by low-cost foreigners on the ships in the Norwegian deep-sea fleet-activity in the North Sea provided not only alternative employment, but jobs that were better paid and had more attractive conditions than what they could find working in conventional deep-sea shipping.

Geological surveys off the Norwegian coast began in the early 1960s, and the first well was drilled by Esso in the summer of 1966. The shipping companies became involved in a number of projects and activities related to the new industry; investment in oil companies, in onshore bases, in supply ships and, as a swarm of bees in the first half of the 1970 s, in oil rigs.

One reason for the shipping companies' involvement was of course the fact that they represented one of the wealthiest industries in Norway. Although "shipping money" typically was reinvested in new transport capacity, shipping companies and shipowners were among the most important capitalists in the country, and a natural starting point for anyone looking for investment funds. Another reason for the inflow of shipping money into the offshore oil sector was the maritime linkages. The offshore oil sector was not the kind of activity that the shipping companies were used to, but it was not far from it. Shipping companies already had substantial competence and relations within areas such as vessel construction and supervision, classification, financing, insurance, manning and son on. This put them in a particularly advantageous position when the offshore petroleum industry was developed.

One example of this bridge between the old and the new maritime interests was the old whale factory ship, Thorshøvdi, which was rebuilt by the Aker Group. A 50-metre drilling tower was added to the almost 20-year-old ship. Renamed Drillship, the former Thor Dahl vessel was 
delivered to British interests in the autumn of 1967. Earlier that year, the first Norwegian-built drilling rig, Ocean Viking, had been delivered to the US company Ocean Drilling \& Exploration Company (Odeco). The rig was responsible for the first major oil find in Norway-what would become the extremely profitable Ekofisk field.

The day before Christmas Eve in 1969, Phillips Petroleum announced that the company had discovered Ekofisk and the economic fate of Norway was changed forever. ${ }^{37}$ However, even before this, shipping interests had entered the offshore sector on a large scale. When Phillips started its activities in 1966, its operations were based at Dusavik, near Stavanger, one of the main supply bases for the offshore industry, and owned by the Stavanger shipping company Smedvigs Tankrederi AS. ${ }^{38}$ However, for most of the Norwegian shipping companies, the first point of entry to the oil sector was investment in oil companies.

Three of Norway's leading shipping companies-Sig. Bergesen d.y. \& Co., Anders Jahre and Fearnley \& Astrup, as well as the Aker Group, where Fred. Olsen was the major owner-participated in the first Norwegian oil consortium, Noco, which was established in 1964. When a second consortium was established the same year, the majority of the owners came from the shipping industry. ${ }^{39}$ The participants in these consortia were mainly the larger Norwegian shipping companies. There was also a handful of other companies that had gained exploration rights, and in the early 1970s more than 30 Norwegian shipping companies had bought shares in such companies. In fact, several of the Norwegian companies with parts in the various oil blocks had only or mainly capital from shipping. KS AS Polaris, AS Pelican Co. KS, AS Syracuse Oils Norge, KS

\footnotetext{
${ }^{37}$ See Kvendseth (1988) for Ekofisk and Hanisch and Nerheim (1992); Nerheim (1996); and Ryggvik and Smith-Solbakken (1997) for a more comprehensive history of the development of the Norwegian offshore oil and gas industry.

${ }^{38}$ See Nerheim and Utne (1990) for the well-written business history of Smedvig, an enterprise that went through the full conversion from a traditional shipping company to an offshore company during the period 1965-1995. Smedvig had also participated, together with a cement company, another shipping company and a shipbroker, in the first Norwegian offshore base.

${ }^{39}$ After the two consortia were merged in 1965,11 of the 20 participating companies had their background within shipping; see Saga Petroleum (1997). Two of the best introductions to the shipping companies' various engagements in the offshore oil industry by the early 1970s, are Seeberg (1974) and Tveit (1973).
} 
25/4 Norsk AS and Scanpet were among the most serious contenders to the large oil companies, and they were all mainly vehicles for shipping companies' investments. ${ }^{40}$ In 1972, Saga Petroleum, the major private Norwegian oil company was established. More than 50 of the 96 companies that participated were shipping companies, and these provided around 60 per cent of the capital. ${ }^{41}$

In addition to their role in establishing and developing the leading private oil companies, shipping interests were important participants when the activity on the Norwegian continental shelf grew rapidly in the early 1970s. One important area was supply shipping. Several of the larger shipping companies invested in supply ships, but this was also a way into the offshore market for new owners with traditions stemming from fisheries or coastal transport. The initial support for the offshore industry came from rebuilt fishing vessels and simple, smaller cargo ships. The first purpose-built vessels were delivered in 1971, and by 1973 there were 24 supply vessels flying the Norwegian flag, with another 46 on order. ${ }^{42}$ The herd behaviour again had consequences for the functioning of the market: as the supply of such ships gradually became plagued by overcapacity, shipowners began to cooperate with regard to management and operations.

Norwegian companies and seafarers had certain advantages in the operation of vessels in the North Sea. They were aware of and used to the difficult conditions, and also had an advantage in dealing with the routines and procedures of Norwegian bureaucracy. Gradually they acquired competence that enabled them to take on new tasks — traditional supply and stand-by services were supplemented by pipe laying, seismic surveys, well intervention and so on.

The historian Helge Ryggvik has referred to the Norwegian shipping companies' advantages within the supply sector as "self-evident." He sees the entry into rig ownership as more surprising, as this activity-despite the mobility of the rigs- had an "industrial" rather than a "shipping"

\footnotetext{
${ }^{40}$ Tveit $(1973,18-27)$.

${ }^{41}$ Calculated on the basis of Tveit $(1973,15-18)$. The other two major Norwegian companies were Statoil, which was fully state-owned, and Norsk Hydro, where the authorities owned the majority of the shares from the early 1970s onwards. See Ryggvik (2000) for a good introduction to the ownership development.

${ }^{42}$ Hanisch and Nerheim (1992, 228-231).
} 
character. This reflected the manner in which the cooperation with foreign interests was organized. Most of the shipping companies that invested in rig ownership initially relied on foreign operators to take care of the drilling-they were "subcontractors, far down in the offshore hierarchy." 43

In the late summer of 1971 Smedvig was the first Norwegian company to order a purpose-built drilling rig, unleashing a veritable flood of new orders; "in the course of a few autumn months nine semi-submersible platforms were ordered, to be registered in Norway." ${ }^{44}$ This signalled the breakthrough for offshore oil in the shipping industry — or the breakthrough for shipping in the oil industry. Almost half of the 25 largest shipping companies participated in the rush for newbuildings in $1971 .{ }^{45}$

The Aker group, in cooperation with the Bergen shipping company Odfjell, developed Aker H-3, a platform specifically designed to cope with the depth and the harsh conditions in the North Sea. The H-3 platform was the focus when the second contracting boom took place, in late 1973 and early 1974. By the end of 1974, 54 drilling rigs had been ordered with Norwegian participation. The Norwegian shipowners brought a new element to the oil industry - speculation. Enticed by the high rates, they ordered rigs without securing employment in advance. ${ }^{46}$ The spot-market strategy that would create enormous problems for Norwegian tanker owners was simply transferred to the rig sector.

The motivation was money. In 1974 the Norwegian rig owners managed to get spectacular rates; two-year contracts at USD32,000 per day for an Aker H-3 platform in January were surpassed by a five-year contract at around USD35,000 per day in May and finally, for Fred. Olsen's Borgny Dolphin, USD 41,000 per day for the next two years. ${ }^{47}$

In 1975 the many rigs that Norwegian owners had ordered began to come on stream, and the market deteriorated. The increasing supply took place against a cooling market, as new taxation rules held the oil companies'

\footnotetext{
${ }^{43}$ Ryggvik (2000, 237).

${ }^{44}$ R.S. Platou, The Platou Report 1971, 23.

${ }^{45}$ See the overview in Tenold (2000, 356-358).

${ }^{46}$ Hanisch and Nerheim $(1992,233)$.

${ }^{47}$ Hanisch and Nerheim $(1992,239)$.
} 
exploration activities back. In 1976 more than 60 new rigs_-leading to a 30 per cent increase of the fleet-were delivered. As supply eclipsed demand, rigs were laid up or rebuilt to dwelling and service platforms. Although the financial situation was more positive than in the shipping sector, oil rig owners could apply for support from the Guarantee Institute, and 13 drilling vessels were included. When the market picked up again in the late 1970s, these engagements were settled without losses.

When shipping was replaced by petroleum as Norway's most important export sector, the competence that had been built up in the shipping companies played a crucial role. Sometimes the two maritime industries worked closely together, for instance in the case of shuttle tankers - ships transporting oil from the offshore fields, as an alternative to pipelines. Improvements in technology revolutionized this manner of moving oil. In 1971 it took almost two months for the Greek tanker Theogennitor to move 34,000 tons of oil from the Ekofisk field to Stavanger. During 2001, when oil production peaked, a fleet of 28 shuttle tankers moved a total of 86.4 million tons of oil, in more than 883 separate voyages. ${ }^{48}$ Compared with Theogennitor, the shuttle tankers' productivity had multiplied by a factor of 15 as a result of economies of scale - the ships varied from 87,000 to $150,000 \mathrm{dwt}$ - and improved loading and discharging equipment.

By the end of the 20th century, Norwegian companies-relying on both capital and competence from shipping-had become world leaders within the advanced, deep-water search for and production of oil and gas. There is a clear upwards trajectory in the value chain when it comes to the Norwegian shipping companies' offshore involvement. As skills were acquired, the foreign operators were replaced by Norwegian managers, operators and personnel.

The increasing offshore activity on the Norwegian continental shelf was a lifeline for many shipping companies, providing new business opportunities and a revenue stream in a difficult time for shipping. However, there were also shipping companies that attempted to enter the offshore sector, and failed. Just as in the shipping industry, strong fluctuations in rates and activity meant that deep pockets-or patient creditors-were an advantage, and at times a necessity.

${ }^{48}$ Lindøe (2009, 19). 


\section{Working (Almost) from Home}

For Norwegian seafarers, the offshore activity was undoubtedly a new and beneficial opportunity. Work was closer to home, with good salaries and shorter periods away from home. Again, the timing was very good. From 1973 to 1981 the number of seafarers employed in the foreigngoing Norwegian fleet declined from 45,000 to 34,000-a reduction of 11,000 seafarers. At the same time, the number of unemployed seafarers hardly increased, from 1143 to 1594 . This 40 per cent growth was in fact lower than for unemployment in general, which increased by more than 90 per cent. ${ }^{49}$

Some of the seafarers left the business altogether, but many started a new working life "offshore." Former seafarers were in high demand. Engineers and other officers "had an education and experience that proved to be extremely valuable in connection with the construction and operation of petroleum installations in difficult North Sea conditions." ${ }^{50}$ It is evident that this was a mutually beneficial arrangement; the seafarers emphasize the "very good" working arrangements offshore, which are "much easier" than in the deep sea fleet. ${ }^{51}$

While the introduction of the NIS saved international shipping under the Norwegian flag in the long term, and many seafarers found attractive employment elsewhere, the 1980s was a tough period for those working at sea. As shipping companies replaced the Norwegians with foreigners, "many sailors suffered mentally and emotionally; they lost their income and standard of living in a very short time." 52 By the start of the 1990s, the more than 6000 seafarers that worked on NOR-vessels in Norwegian waters also saw increased competition. The basis was foreign companies, sometimes subsidized, from other European countries.

From 1965 to 1973, in the growth period before the shipping crisis had started to bite, the number of Norwegian seafarers fell by around a third, as a result of rationalization and economies of scale. From 1973

\footnotetext{
${ }^{49}$ Norway, Parliament, NOU 1983, Skipsfartens konkurranseevne, 76-77.

${ }^{50}$ Hanisch and Nerheim $(1992,365)$.

${ }^{51}$ Mack $(2007,352)$.

${ }^{52}$ Mack $(2007,353)$.
} 
until the introduction of the NIS in 1987, the number was halved, to around 17,000, as ships were sold abroad and flagged out. ${ }^{53}$ By the year 2000 , employment had increased to almost 15,000 Norwegian seafarers on NOR-vessels and almost 4000-mainly officers-on NIS-vessels, in addition to those that worked on ships flying other flags. ${ }^{54}$

Although the decline in employment halted, and was even reversed, the cultural impact of employment on Norwegian ships has changed dramatically. As late as the 1970s, around a third of the male labour force had spent some time at sea. For many, it was a temporary adventure and a way to see the world in the period before mass travel and cheap airplane tickets. For others, it was a means of escape. Up until the 1970s, a stint at sea was seen as the best way to instil discipline and a sense of responsibility in "unruly boys." Today, there are few acceptable alternatives.

In the old days, those working in the cafes and bars in the main ports had a special trick to deal with drunken sailors: when they threw them out of the establishment, they would put their hats on back-to-front. This would make it very clear for the next bar owner that these sailors had had too much to drink, and should be sent back to their ship, rather than be served. ${ }^{55}$

Today, the hats, the red-light districts and adventure-seeking Norwegian sailors in exotic ports have gone. Bergen Bar, Tønsberg Bar and Café Håpløs have closed their doors. Most Norwegian seafarers have returned home. They are no longer the "heroes who came home" telling "about the world or their life experiences," no longer the explorers that "carried the Chesterfields in their pockets and were naturally tanned in the middle of winter." 56

Today, all kinds of Norwegians go abroad. But the seafarers have largely returned home. The busiest seamen's church-now rebranded as the "Norwegian Church Abroad" - is the one at Gran Canaria, and around a third of the resources that the seamen's church has is used in Spain. The majority of the European seamen's churches are not in important port

\footnotetext{
${ }^{53}$ Calculated on the basis of Statistics Norway (1994, 487).

${ }^{54}$ Norway, Parliament, Stortingsmelding 31 (2003-2004), 30.

${ }^{55}$ Marthinsen (1998, 61).

${ }^{56}$ Mack $(2007,351)$.
} 
cities, but in tourist destinations, both on the coast and inland. However, there are also seven chaplains working on the oil platforms on the Norwegian continental shelf, and another three involved with supply vessels. ${ }^{57}$

The plan that Erling Dekke Næss presented in 1984 saved Norwegian deep-sea shipping under the Norwegian flag, but it was too late to save most of the seafarers in the ocean-going Norwegian fleet.

\section{Bibliography}

F. Bacon (1842) 'Cape Palmas and the Mena, or Kroomen', The Journal of the Royal Geographical Society of London, 12, 196-206

D. Bakka (1999) I hardt var. Skipsfartskrise og samlingsprosess - Norsk Sjøoffisersforbund 1995 (Bergen: Norsk Sjøoffisersforbund)

D. Bakka (2017) Nasjonens are - Norsk rederinering mellom marked og politikk (Bergen: Bodoni Forlag)

J.G. Bjørklund \& B. Kolltveit (1989) 'Norsk sjøfart i det 20. århundre', in B. Berggren, A.E. Christensen \& B. Kolltveit (eds) Norsk Sjøfart (Oslo: Dreyers Forlag AS) 126-311

R. Carlisle (2009) 'Second Registers: Maritime Nations Respond to Flags of Convenience, 1984-1998', The Northern Marinerlle marin du nord, 19:3, 319-340

J.O. Egeland (1930) 'Norges sjøfart. Hvad den var og hvad den er', in G. Stenersen (ed) Sjømannsboken; sjøfart, hvalfangst, marine: orientering i sjømannskap, veiledning til selvstudium, (Oslo: Norsk bibliotekforening) 3-37

H. Espeli (1999) Lobbyvirksomhet på Stortinget (Oslo: TANO Aschehoug)

T. Halvorsen (2010) 'Vi var "degos, svartinger eller skjevøyde”. Utlendinger i den norske handelsflàten 1950-75', Arbeiderhistorie, 24, 203-223

M. Hammerborg (2003) Skipsfartsbyen (Bergen: Eide)

T.J. Hanisch \& G. Nerheim (1992) 'Fra vantro til overmot', Norsk Oljehistorie 1 (Oslo: Norsk Petroleumsforening)

W.J. Harvey (2005) Kristian Jebsens Rederi AS Bergen - A Group History (Windsor: The World Ship Society)

L.C. Jenssen (1999) '50 år i stampesjø' - Fagbevegelsens kamp mot bekvemmelighetsflagg’, Arbeiderhistorie, 13, 203-223

\footnotetext{
${ }^{57}$ Sjømannskirken, Annual report 2017.
} 
R. Kvam (1971) Den billige arbeidskraften (Oslo: Pax Forlag AS)

S.S. Kvendseth (1988) Funn! Historien om Ekofisks forste tyve àr (Stavanger: Phillips Petroleum)

J.O. Lindøe (2009) From sea to shore - the shuttle tanker story (Stavanger: Wigestrand Forlag \& Stavanger Maritime Museum)

K. Mack (2007) 'When seafaring is (or was) a calling: Norwegian seafarers' career experiences', Maritime Policy \& Management, 34:4, 347-358

T.-O. Marthinsen (1998) Sjømann - vel fortjent i trygg havn (Stavern: Det nasjonale aldershjem for sjømenn i Stavern)

S. Molaug (1977) Sjøfolk forteller - Hverdagshistorier fra seilskutetiden (Oslo: Tanum-Norli)

G. Nerheim (1996) "En gassnasjon blir til,” Norsk Oljehistorie 2 (Oslo: Norsk Petroleumsforening)

G. Nerheim \& B.S. Utne (1990) Under samme stjerne - Rederiet Peder Smedvig 1915-1990 (Stavanger: Peder Smedvig AS)

E.D. Næss (1977) Autobiography of a Shipping Man (Seatrade, London)

E.D. Næss (1981) Shipping - mitt liv (Oslo: AS Hjemmet Fagpresseforlaget)

H. Phillips (1889) 'An Account of the Congo Independent State', Proceedings of the American Philosophical Society, 26:130, 459-476

H. Ryggvik (2000) Norsk oljevirksomhet mellom det nasjonale og det internasionale. En studie av selskapsstruktur og internasjonalisering (Oslo: Senter for Teknologi, Innovasjon og Kultur)

H. Ryggvik \& M. Smith-Solbakken (1997) 'Blod, svette og olje', Norsk Oljehistorie 3 (Oslo: Norsk Petroleumsforening)

Saga Petroleum (1997) Sagaen om Saga (Oslo: Saga Petroleum ASA)

B. Seeberg (1974) 'Norsk skipsfart og dens engasjement i petroleumsaktivitetene i Nordsjøen', unpublished thesis (Bergen: Norwegian School of Economics and Business Administration)

G.K. Sletmo \& S. Holste (1993) 'Shipping and the competitive advantage of nations: The role of international ship registers' Maritime Policy and Management, 20:1, 243-255

H. Sornn-Friese \& M.J. Iversen (2014) 'The establishment of the Danish International Ship Register (DIS) and its connections to the maritime cluster', International Journal of Maritime History, 26:1, 82-103

Statistics Norway (1994) Historisk Statistikk 1994 (Oslo: Statistisk Sentralbyrå)

S. Tenold (2000) 'The Shipping Crisis of the 1970s: Causes, Effects and Implications for Norwegian Shipping', PhD-thesis (Bergen: Norwegian School of Economics and Business Administration) 
S. Tenold (2001) Skipsfartskrisen og utviklingen i norske skipsfart 1970-91 (Bergen: Stiftelsen for samfunns- og næringslivsforskning)

S. Tenold (2015a) Geared for Growth. Kristian Gerhard Jebsen and His Shipping Companies (Bergen: Bodoni Forlag)

S. Tenold (2015b) 'Globalisation and maritime labour in Norway after World War II', The International Journal of Maritime History, 27:4, 774-792

E. Tonkin (1974) 'Review of The Kru Mariner in the Nineteenth Century: An Historical Compendium', The Journal of African History, 15:2, 332-334

O.K. Tveit (1973) Nordsjøoljen (Oslo: Grøndahl \& Søns Forlag)

P.M. Vigtel (1988) 'Norsk Internasjonalt Skipsregister - årsak og virkninger', Norsk Utenrikspolitisk Årbok (Oslo: Norsk Utenrikspolitisk Institutt) 83-93

D. Vikøren (1967) 'Merchant Marine Policy of Norway', manuscript (Oslo: Norwegian Shipowners' Association)

Open Access This chapter is licensed under the terms of the Creative Commons Attribution-NonCommercial-NoDerivatives 4.0 International License (http:// creativecommons.org/licenses/by-nc-nd/4.0/), which permits any noncommercial use, sharing, distribution and reproduction in any medium or format, as long as you give appropriate credit to the original author(s) and the source, provide a link to the Creative Commons license and indicate if you modified the licensed material. You do not have permission under this license to share adapted material derived from this chapter or parts of it.

The images or other third party material in this chapter are included in the chapter's Creative Commons license, unless indicated otherwise in a credit line to the material. If material is not included in the chapter's Creative Commons license and your intended use is not permitted by statutory regulation or exceeds the permitted use, you will need to obtain permission directly from the copyright holder.

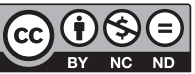

